AMERICAN JOURNAL OF SOCIAL AND MANAGEMENT SCIENCES

ISSN Print: 2156-1540, ISSN Online: 2151-1559, doi:10.5251/ajsms.2012.3.3.112.120

(C) 2012, ScienceHuß, http://www.scihub.org/AJSMS

\title{
Dimensions of fraud in Nigeria quoted firms
}

\author{
Dr. D. I. Hamilton and Justin M. Odinioha Gabriel \\ Department of Management, Faculty of Management Sciences, E-mail: urokad2006@yahoo.com \\ Phone: 08033400853
}

\begin{abstract}
This study examined the management of financial fraud in quoted companies in Nigeria. Employing a sample of 22 firms and Using the questionnaire and oral interviews as study instruments, data were obtained, and analyzed using simple percentages and frequency distribution tables. Some findings of the study are that-: (a) poor internal systems are the major cause of fraud in Nigeria organizations (b) Funds diversion is the commonest kind of fraud; (c) most business organizations do not make fraud cases public. (d) Young people within the age brackets of 31-40 years and polygamists recorded highest cases of involvement in fraudulent acts among the employees. (e) The frequency of Males involvement in fraudulent act surpassed that of females. The study however concludes that even though fraud cannot be completely eliminated from our business life, its occurrence can be minimized through better internal control systems and by placing those personality types with the least propensity to commit fraud in sensitive and vulnerable positions.
\end{abstract}

Key Words: Fraud, Management, Corruption, Bribery and Crime.

\section{INTRODUCTION}

Nigeria as a nation is deeply soaked in, and characterized by, fraud and its related corrupt practices. These have had severe negative consequences on the country and its global image. Fraud and related ills have caused instability in the economy resulting to a high mortality rate of business organizations and the consequent losses of revenues.

Business practices in Nigeria have been equally marred by incredible waves of fraud, involving misappropriation of funds, cheque forgeries, funds diversion, etc. As in the society at large, frauds has become one of the most intractable problems of modern day business in Nigeria. While public concern is growing by the day and management vigilance improving with the aid of computerization, it is on record that millions of naira are lost to fraud and forgeries which Stanley (1994) had argued results in huge financial losses to business organizations and their customers, depletion of shareholders' funds and capital base as well as loss of confidence in businesses.

It cannot in anyway be considered an exaggeration to posit that the worst enemy of our business both in the past and present is fraud. Mismanagement may have put our country's economy in its present predicament. However, it cannot be contested that the high incidence of fraud has played even greater role in this respect. Over the years only the banking sub-sector among others in the Nigerian economy has received some attention on fraud related matters. Hence, Nwachukwu (1995), wrote that more money is stolen in or through banks by means of fraud committed with pen than through other means. Just as the banks are hit, so also are other business organizations. Fraud may take the form of theft of inventory assets, misuse of expense account, secret commission and bribery, false invoicing, electronic and telecommunication fraud, unauthorized use of information, cheque forgery, false financial statements, and so on, but whichever form it takes, the fundamental point is that the business organization that falls victim to fraudulent acts suffers and bears the brunt.

Fraud has become a cost of doing business, a crime of the millennium, which can affect anyone, anytime, anywhere, and it respects no boundaries. To make matters worse, the expansion of global financial markets has offered international criminals many more opportunities that has resulted in an increased number of reported cases of fraud globally (Stanley, 
1994). This study is designed to investigate the dimensions of fraud in business organizations in Nigeria. To achieve the purpose of this study the following research questions have been formulated.

What kinds of fraud occur in Nigerian business organizations?

What are the causes of fraud in these business organizations?

How are the fraud cases treated?

How can the occurrence of fraud be minimized or checkmated?

What categories of people are mostly involved in the act of fraud?
According to Robertson (1976), fraud is any deception practiced to cheat or deceive another to his own detriment or to the detriment of any other, or to cause another loss or injury, while the perpetrator has a clear knowledge of his deliberate falsehood, deceptions or advantage over the innocent and unsuspecting victim. Similarly, Stanley (1994) defined fraud as consisting of knowingly making material misrepresentations of facts, with the intent of inducing someone to believe the falsehood and act upon it, thus suffering a loss or damage. This definition encompasses all the varieties by which people can lie, cheat, steal and dupe others. Elliot and Willingham (1980) diagrammatically represented the nature of corporate fraud as displayed in figure 1 below:

\section{Figure 1: Abundance of Fraud}

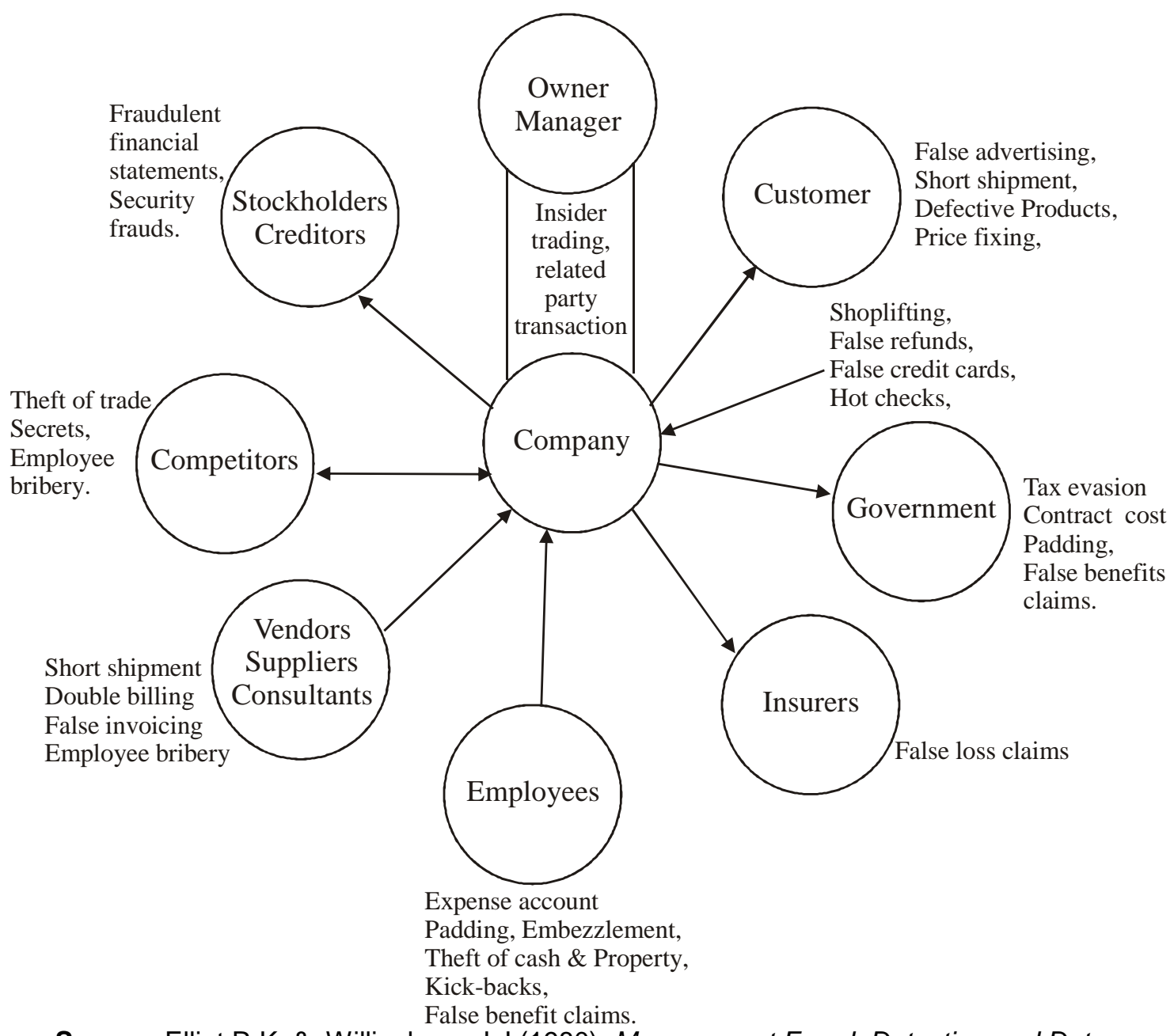

Source: Elliot R.K. \& Willingham. J.J (1980): Management Fraud: Detection and Deterrence, New York;

Pettrocelli Books, Inc. 1980 p.4 
Radzinowicz and Wolfgang (1997) classified fraud together with white - collar crime and defined them as "illegal acts characterized by guilt, deceit and concealment and are not dependent upon the application of physical force or violence or threats thereof". Using similar terms, Adekanya (1986) Ojo and Adewunmi (1986), Ojigbede (1986) and Sydney (1986) in their definitions, agreed that fraud is an action which involves the use of deceit and tricks to alter the truth so as to deprive a person of something which is his or something to which he might be entitled.

Kirkpatrick (1985), in his view noted that a person who pretends to be something that he is not is a fraud, a snare, a cheat and a swindler. Fraud is therefore considered to involve elements of dishonest practice, deception, false disclosure, concealment of assets and other activities of this nature. Fraud was equally defined as a deceit, trickery, or cheating by Smith (2002), as a threat to security, and as an act which relieves people of their valuable possessions and brings about unparalleled hardship to known and unknown victims by Smith and Grabosky (1998).A careful assessment of all the afore- discussed meanings of fraud reveals that fraud involves elements of dishonest practice, deception, false disclosure, concealment of assets and other activities of related kinds. This points to the fact that most scholars agree with each other on the meaning of fraud.

Kinds of Fraud: According to Robertson (1976 and 1979) fraud can be perpetrated in different ways; some of these will include: employee fraud, embezzlement, larceny, defalcation and management fraud. Similarly, some authorities such as the committee of chief inspectors of Banks (1996) and Sydney (1986) prefer to group fraud according to the perpetrators. Others like Adekanya (1986), Adewunmi (1986) and the Bankers Administration Institute (1987) prefer a classification based on the methods used. On the basis of perpetration, there are three broad categories: internal perpetration of fraud by staff, external perpetration by outsiders and mixed fraud by both outsiders and insiders (Iwuagwu: 2000) The types of fraud are usually not exhaustive as fraudsters are forever devising new methods. According to Rochschild (1994), the most important and common kinds of fraud include: Investment fraud, banking and financial service fraud, government fraud, marine fraud, computer fraud and, smash and grab fraud.

Fraud Prevention and Control: Accountants and auditors have often been exalted to be the leaders in fraud prevention by employing their skills in designing 'tight' control systems. This strategy however is at best a short-run solution to a large and pervasive problem. Business activities are built on the trust that people at all levels will do their jobs properly. Control systems limit trust, limit employee's initiatives and in the extreme, can strangulate business organizations with bureaucracy. Managers and employees must have freedom to do business which may sometimes mean giving them freedom to commit fraud. Effective long-run prevention measures are complex and difficult, and involves the elimination of the causes of fraud by mitigating the effects of motive, opportunity and lack of integrity (Robertson, 1976).

Oju (1994) and Sydney (1996) have identified some management control systems that have been devised by banks to prevent fraud. Sydney (1986) defined management control system as " the whole of controls, financial and otherwise, established by the management, in order to carry on the business of a company in an orderly manner, safe-guard its assets and secure as far as possible the accuracy and reliability of records." He further classified internal management control systems into two: internal checks and internal audit. Internal checks are the operational controls which are built into the banking system to simplify the processing of entries in order to secure prompt services, to help in minimizing clerical errors and to act as insurance against collusion. Internal audit or inspection involves the review of operations and records undertaken within a business by specifically assigned staff.

Oju (1994) also classified existing systems of control into two, those aimed at prevention and those aimed at detection. Measures aimed at fraud prevention includes dual control, operational manual, graduated limits of authority, lending limits, reporting systems, micro-filming, close circuit television, establishment of inspectorate units, time clock devices, general personnel policies, referencing on presentation of documents of value, segregation of duties, verification of signatures, control of dormant accounts, retention of passport-size photographs, close watch on the lifestyle of staff, and lodging, decoding and testing. Others are the observation of 
laid down procedures for opening and closing of accounts and the use of regiscope camera to photograph persons drawing large sums of money.

More so, the measures aimed at fraud detection include checking of cashiers, call-over, reconciliation branch, inter branch and head office levels; periodical submission of statements of accounts, stock taking of security items and cash in the vaults and inspection by bank inspectors. Nnamdi (1991) attributed the ineffectiveness of these measures to weakness in staff policy and control, operational procedures, and the attitude of management. In contrast, some other authors have argued that the cause of frauds is not necessarily that of lack of management control systems but that of moral weakness of man's mind owing to his acquisitive instincts.

Whistle blowing, a fraud detection mechanism, is generally defined as the disclosure of illegal, unethical or harmful practices in the workplace to parties who might take action (Rothschild \& Miethe, 1994). In general, an activity is seen as whistle blowing if the disclosure is considered to be in the public interest. This will entail information about criminal activity, a contravention of a statutory requirement, improper or unauthorized use of public and other funds, miscarriage of justice, abuse of power, misadministration, danger to the health or safety of any individual and any other misbehaviour or malpractice (Kloppers, 1992) Some theorists argue that whistle blowing only takes place when the information is placed on record publicly. Alant and Uys (1999) however, argue that whistle blowing includes going outside the normal chain of command or the unwarranted exercise of power with the motive of gaining some advantage more or less directly personal.
Whatever strategy that is adopted in controlling fraud, evidence exists that the traditional technique of management control can also be employed in our context. Juju, it seems could control the behavior of Nigerian workers and its oracle can reveal truths hidden in the minds of people and in the dark places of crime (Asechieme,1998).

\section{METHODOLOGY}

This research was carried out in Port Harcourt, the heart of the hydrocarbon industry in Nigeria and the center of business activities outside Lagos. 22 quoted companies were sampled from a list of 23 quoted companies listed on the stock exchange as at February 2006. Due to the sensitive nature of the subject of our study, we did not deem it germane and rational to issue our instrument to every cadre of staff, rather we chose the managers of different departments who we considered competent to respond to our questions. The yardstick used includes whether such manager is in control of valuables, and if fraud matters go to his or her table. Managers of inventories, production, sales, finance and accounting departments were reached. For each firm, three copies of the questionnaire were issued to three respondents, bringing the total number of copies of the questionnaire issued to 66 . Unfortunately only 32 copies of the questionnaire were returned. Nigerians obviously do not want to be quoted on fraud and related matters.

\section{RESULTS}

\section{Types of fraud}

Several types of fraud are reported in literature. (see Robertson, 1976, and 1979), Table 1 presents the types of fraud that are prevalent in business organizations in Nigeria.

Table .1: Types of Fraud in Nigerian Business Organizations

\begin{tabular}{|l|c|c|}
\hline Types of Fraud & $\begin{array}{c}\text { Frequency } \\
\mathbf{n = 3 2}\end{array}$ & Percent \\
\hline Funds diversion & 21 & 65.5 \\
Secret commission \& bribery & 10 & 31.5 \\
False invoicing & 10 & 31.5 \\
Theft of inventory assets & 9 & 28.1 \\
Cheque forgery & 6 & 13.8 \\
\hline
\end{tabular}

Source: Research Data, 2012

prevalent kind of fraud in Nigerian business firms.

Table 1 shows that 65.5 percent of the respondents are of the opinion that funds diversion is the most
31.5 percent indicated that it is secret commission and bribery, another 31.5 percent of the respondents 
opted for false invoicing, 28 percent of the respondents said it was theft of inventory assets, and 13.8 percent said it was cheque forgery

Causes of Fraud: Occurrence of fraud in business had been attributed to several factors as earlier discussed in Adekanya (1986), Ekechi (1990), Ovuakporie (1994), and Desmond (1986). Table 2 presents the causes of fraud in Nigerian business organizations

Table 2 Causes of Fraud in Nigerian Business Organizations

\begin{tabular}{|l|c|c|}
\hline \multicolumn{1}{|c|}{ Courses of Fraud } & $\begin{array}{c}\text { Frequency } \\
\mathbf{n = 3 2}\end{array}$ & Percent \\
\hline Poor internal control & 15 & 46.9 \\
Poor hiring practices & 12 & 37.5 \\
Lack of accountability & 9 & 28.1 \\
Poor ethical values & 4 & 12.5 \\
Poor physical security & 1 & 3.0 \\
others & 1 & 3.0 \\
\hline
\end{tabular}

Source; Research Data, 2012

Table 2 shows that 46.9 percent of the respondents said that fraud was caused by poor internal control system, 37.5 percent blamed the occurrence of fraud on poor hiring practices, 28.1 percent heaped it on the lack of accountability, 12.5 percent opted for poor ethical values, while 6 percent said it was as a result of poor physical security and other unnamed reasons.
Handling for Fraud Cases: Firms that had been defrauded at one time or the other had handled the matter using one measure or the other. Table 3 presents some ways fraud cases had been treated in Nigerian firms.

Table 3 Treatment of Fraud Cases

\begin{tabular}{|l|c|c|}
\hline \multicolumn{1}{|c|}{ Treatment Measures } & Frequency \\
$\mathbf{n = 3 2}$ & Percent \\
\hline Immediate dismissal and disciplinary action. & 18 & 56.3 \\
Reported to the police & 8 & 25 \\
Kept quiet & 7 & 21.9 \\
Negotiated settlement & 6 & 18.8 \\
Civil actions for recovery & 1 & 3.1 \\
\hline
\end{tabular}

Source: Research Data, 2012

Table 3 shows that 56.3 percent of our respondents indicated that fraudsters were either immediately dismissed or disciplinary actions followed, 25 percent said that such cases were reported to the police, 21.9 percent said their organizations kept quiet, 18.8 percent said their organizations negotiated settlement, while 3.1 percent said their organizations took legal action for recovery.
Reduction of Fraud: Due to the colossal dangers associated with fraud, several efforts are made to ensure its minimization. Table 4 presents some techniques that Nigerian firms had adopted in the past. 
Am. J. Soc. Mgmt. Sci., 2012, 3(3): 112-120

Table 4. Fraud Reduction Strategies

\begin{tabular}{|l|c|c|}
\hline Strategies of Fraud Reduction & $\begin{array}{c}\text { Frequencies } \\
\mathbf{n = 3 2}\end{array}$ & percent \\
\hline Institution of internal control system & 18 & 56.3 \\
Summary Dismissal and make refunds & 9 & 28.1 \\
Simply dismiss \& let go & 4 & 12.5 \\
Seek legal remedy & 3 & 9.4 \\
Any other & 2 & 6.3 \\
\hline
\end{tabular}

Source; Research Data, 2012

Table 4 shows that 56.3 percent of the respondents maintained that an internal control system be instituted to check fraud, 28.1 percent indicated that fraudsters should be summarily dismissed and compelled to make refunds as a way to deter intending fraudsters, 12.5 percent advised that fraudsters should simply be dismissed and relieved of their job without any further punishment, while 9.4 percent said business firms should seek legal remedies.

Consequences of Fraud: Organizations defrauded at one time or another were affected differently depending on their status and nature of business. Table 5 reports some consequences of fraud among quoted firms operating in Nigeria.

Table 5. Effect of Fraud on Business Organizations.

\begin{tabular}{|l|c|c|}
\hline \multicolumn{1}{|c|}{ Consequences of Fraud } & $\begin{array}{c}\text { Frequency } \\
\mathbf{n = 3 2}\end{array}$ & Percent \\
\hline & & 87.5 \\
Loss of profit & 28 & 43.8 \\
Depletion of shareholders' funds. & 14 & 21.9 \\
Negative corporate image. & 7 & \\
\hline
\end{tabular}

Source; Research Data, 2012

Table 5 shows that 87.5 percent of the respondents said that fraud caused loss of profit to their organizations, 43.8 percent said it depleted shareholders' funds, while 21.9 percent said it caused negative corporate image.
Managers of business in Nigeria have found it difficult to know the kind of people to be treated with caution in relation to fraud in the organization Table 6 presents the personality profile and level of involvement of those who had been guilty of fraud at one point or another.

\section{Who are the Fraudsters?}

Table 6. Personality Profile of Fraudsters and their Level of Involvements

\begin{tabular}{|l|c|c|l|c|c|}
\hline \multirow{2}{*}{ Personality Dimensions } & \multicolumn{5}{|c|}{$\begin{array}{c}\text { Level of involvement } \\
\text { (n=32) }\end{array}$} \\
\cline { 2 - 6 } & $\begin{array}{c}\text { Very high } \\
\text { involvement }\end{array}$ & $\begin{array}{c}\text { High } \\
\text { involvement }\end{array}$ & $\begin{array}{c}\text { Average } \\
\text { Involvement }\end{array}$ & $\begin{array}{c}\text { Low } \\
\text { involvement }\end{array}$ & $\begin{array}{c}\text { Weighted } \\
\text { Total. }\end{array}$ \\
\hline Age : & $2(10)$ & $4(16)$ & $8(24)$ & $5(10)$ & 60 \\
(a) $21-30$ years & $15(75)$ & $7(28)$ & $5(15)$ & - & 118 \\
(b) $31-40$ years & $4(20)$ & $4(16)$ & $7(21)$ & $4(8)$ & 65 \\
(c) $41-$ above & & & & & \\
\hline
\end{tabular}




\begin{tabular}{|c|c|c|c|c|c|}
\hline $\begin{array}{l}\text { Marital Status: } \\
\text { (a) Single } \\
\text { (b) Monogamist } \\
\text { (c) Polygamist } \\
\text { (d) Divorced }\end{array}$ & $\begin{array}{c}6(30) \\
10(50) \\
16(80) \\
-\end{array}$ & $\begin{array}{c}7(28) \\
8(32) \\
5(20) \\
1(4)\end{array}$ & $\begin{array}{l}6(18) \\
5(15) \\
- \\
4(12)\end{array}$ & $\begin{array}{c}2(4) \\
- \\
- \\
7(! 4)\end{array}$ & $\begin{array}{c}86 \\
97 \\
100 \\
28\end{array}$ \\
\hline $\begin{array}{l}\text { Religion: } \\
\text { a) Born again Christians } \\
\text { b) Church goers } \\
\text { c) Muslims } \\
\text { d) Other religions } \\
\text { e) Atheists }\end{array}$ & $\begin{array}{c}3(15) \\
5(25) \\
5(25) \\
- \\
-\end{array}$ & $\begin{array}{c}1(4) \\
8(32) \\
3(12) \\
5(20) \\
4(16)\end{array}$ & $\begin{array}{l}3(9) \\
4(12) \\
5(15) \\
4(12) \\
2(6)\end{array}$ & $\begin{array}{c}5(10) \\
- \\
- \\
- \\
3(6)\end{array}$ & $\begin{array}{r}38 \\
69 \\
52 \\
32 \\
{ }^{*} 28\end{array}$ \\
\hline $\begin{array}{l}\text { Gender: } \\
\text { a) Males } \\
\text { b) Females }\end{array}$ & $\begin{array}{c}18(90) \\
-\end{array}$ & $\begin{array}{l}6(24) \\
4(16)\end{array}$ & $\begin{array}{l}- \\
9(27)\end{array}$ & $\begin{array}{c}- \\
9(18)\end{array}$ & $\begin{array}{l}114 \\
61\end{array}$ \\
\hline
\end{tabular}

Source: Research Data 2012

This score can be explained by the low prevalence of atheists in the workforce.

Age: Table 6 shows that employees in the 31-40 years age bracket are the most involved in fraud. This bracket has the highest weighted total of 118 . This is followed by the 41 years and above age bracket with a weighted total of 65 the least is the 21 30 years age bracket.

Marital Status: For marital status, Polygamists were most involved in fraud with a weighted total of 100 . this was followed by the monogamist (with a weighted total of 97), singles (86) and lastly divorced with 28 weighted total points.

Religion: With respect to religion and religiosity mere church goers had the greatest involvement with a weighted total score of 69 . This is followed by Muslims (52 points), born again Christians (38 points) other religions (32) and atheists (28 points).

Gender: With regards to gender, males were more involved in financial fraud, with weighted total score of 114 points are opposed to the law level of female in involvement, with only a weighted total of only 61 points.

\section{DISCUSSION OF FINDINGS}

Poor internal control remains the greatest cause of fraud in Nigerian business Organizations. This is followed by poor hiring practices. This finding corroborates those of Adekanya, (1986), Ekechi,(1990), and Fagbemi (1986)According to Adekanya (1986) . Internal control remains the panacea for the minimization of fraud among businesses in Nigeria.. This is because of the belief that prevention is better than cure. This result is in tandem with Robertson's (1976) conclusion in which he opined that internal control will make it difficult for any individual to have absolute power that can simplify fraud. He opined that internal control will bring about separation of duties and make fraudulent acts difficult.

Funds diversion is the most prevalent kind of fraud in Nigerian business organizations. This result is not in tandem with Ovuakporie's (1994) finding which failed to identify funds diversion but listed theft and embezzlement, defalcation, forgeries, suppression, fraudulent substitutions, payment against unclear effects, unauthorized lending as the most prevalent types of fraud. The differences in our respective findings may have resulted from the differences in the size of organizations studied. In smaller organizations, employees may not have access to facilities that can make diversion of fund easy, rather the kind of fraud that may be common include false invoicing, secret commission, bribery and theft and not funds diversion.

We also found that the commonest action against fraudsters had been disciplinary hearing and immediate dismissal from employment. This position has never helped matters because a man who has stolen colossal sums of money from an organization and is simply dismissed without punitive measures will go home as a king and a celebrity in a base society like that of Nigeria. Perhaps this is why fraud 
is on the increase in Nigerian firms, since wealth no matter how obtained is adored and worshipped. Most business organizations kept quiet in the face of fraud. We found that the avoidance of negative publicity and the fear that virtually everyone has skeletons in his cupboard were the reasons why organizations sometimes maintain silence in the face of fraud. Adekanya (1986) holds similar views

Young people within the ages of 31-40 years are the most involved in fraud, followed by those of 41 years and above. This finding is realistic because the age bracket of 31-40 years is where Nigerians begin to assume serious responsibilities,

Many Nigerian studies of indigenous entrepreneurship (Ottih, 2000 and Okia-Anie, 1994, among others) have found this age bracket that model age bracket for entrance into entrepreneurship. It is the age venturing. Polygamists are the most involved in fraud. The reason may be because, the higher the number of wives, the greater the number of children, children and wives are social and economic projects that are difficult to abandon, hence the man may seek means of additional income, not minding its source.

Religious fanaticism is no immunity from fraudulent actions; by this we mean that people who claim to be Christians or Muslims were also found to be fraudsters. People wear the mask of religion in order to divert attention from themselves as possible fraudsters; such people are usually the last to be suspected in the event of any fraud in the business firm.

Males have a higher propensity to commit fraud than their female counterparts This finding is harmonious with those of most studies on the effect of gender on ethical issues (Hoffman 1998, Beltramini et el 1984; Barnett et al, 1987. This is possibly because they have the responsibility to take care of the family and more so, are more hardened than the females who cannot withstand the slightest of public umbrage and police harassment. Another explanation to this may be that there are more males in high corporate positions than females.

\section{CONCLUSION AND RECOMMENDATIONS}

It is obvious that corporate financial fraud is common in Nigeria and this is exacerbated by the facts that efforts to control it have been haphazard, punishment to fraudsters have been Lukewarm, as culprits are often dismissed with their loots unrecovered and cases are sometimes not even reported to the police. Male of 31 to 40 years age bracket are the most involved in corporate financial fraud, and religion and religiosity does not stop people from committing fraud, but are actually umbrella where some mask themselves while doing their heinous things. Findings from the current study definitely offer practical value for managers and organizations with respect to the management of fraud.

The disparity among organizational managers and employees in their propensity to commit fraud, as offered by such variable as gender, religion and religiosity, age and marital status appear to be beneficial in the management of fraud. In the first instance, it provides a guide as to what personality is most suited for appointment into sensitive and tempting position. In the second place, it provides a check and control device whereby personality profiles with very low propensity for fraud can be injected into organizational units, departments and committees responsible for decisions and actions relating to finances, such as contracts and purchases. Differing ethical values among organizational employees will not only check the engagement in fraud but also help to minimize the chances that a firm will engage in unethical practices.

\section{REFERENCES}

Barnett, J. and Karson, M. (1987) "Personal Values and Business Decision: An Exploratory Investigation" Journal of Business Ethics, 6:371-383

Adekanya F. (1986): "Fraud in Banking Transactions, The Nigerian Banker Vol. 1, No 6

Adewumi W. (1986): Fraud in Banks - An overview.: Landmark Publication Ltd. Lagos

Beltramini, R, Peterson, R. and Kozmetsky, G (1984) "Concerns of college students Regarding Business Ethics" Journal of Business Ethics 3: 195 -200

Alant, N. \& Uys T. (1999), "Whistle blowing, fighting fraud in organizations" a paper presented at the conference on fraud and African Renaissance at Uganda Martyrs University:

Asechieme, D.P.S. (1998), "Management Control among informal sectors entrepreneurs in Nigeria; some initial evidence", West African Journal of Business, Vol. 1 No.1 July/Dec. pp. 1-8.

Nwachukwu C.C (1995), Modern Nigerian Business Law. African Educational Service Owerri, Nigeria. 
Desmond, S. (1986), Elements of Banking 1 \& 2 Financial Training Publisher Ltd., London.

Elliot R. K \& Willingham (1980) Management Fraud: Detection and Deterrence Pettro Celli Books Inc. New York.

Ekechi A. O. (1990) "Fraud and forgeries in Banks: Causes, Types and Prevention" A paper presented at a National Seminar on Banks Audit organized by the Institute of Chattered Accountants of Nigeria Lagos.

Fagbemi, B. (1985), "Fraud in Banking Transactions" The Nigerian Banker Vol. 6 No. 1. P 20

Fagbemi O. A. (1986) Fraud in Banks: The law and legal process, N.B and marks publications Ltd, Lagos

Hoffman, J. J. (1998) "Are Women Really More Ethical than Men? Maybe it depends on the situation" Journal of Managerial Issues. Vol. X, No.1, spring : 60-73

Klopper P. (1992) "Behoort die whistle blower besker te word?" Stellenbosch law review, 8 (2): 237 - 248.

Iwuagwu, O. (2000) "Corruption: A threat to Democracy and National Development", Journal of National Economic Group of Nigeria (Jan - March 2002) Vol. 8 No.1. pp.12-16

Kirkpatrick E. M. (1985): Chambers Universal Learners Dictionary Spectrum Book Ltd Ibadan.

Nnamdi Asika (1991): Research Methodology in the Behavioural Science. Lagos: Longman Nigeria Ltd.

Ojigbede S. I. (1986) "Fraud in Banks" An unpublished paper presented at an effective Bank inspectors course organized by FITC in Lagos, between $6^{\text {th }}$ and $17^{\text {th }}$ October, 1986

Okia- Anie, I A. (1994) "Venture Characteristics and success: A study of selected Entrepreneurships in Port Harcourt" Unpublished M.B.A thesis, Rivers state Univeristy of science and Technology, Port Harcourt. Nigeria

Ottih, L. O (2000) Entrepreneuring: Toward Preparedness "Pearl publishers, Port Harcourt, Nigeria.
Ojo \& Adewanmi (1982): Banking and Finance in Nigeria CIBN \& Landmark publication Ltd. Lagos.

Oju, M.O. (1994) "Checking Unethical Practices in the Financial System: Implications for the economy", A Seminar paper presented at Mason centre Lagos.

Ovuakporie V. (1994): Bank Frauds: Causes and Prevention. Ibadan: ATT Books.

Rothschild M (1994): as cited in Alant N \& Uys T (1994): Whistle blowing fight fraud in the organizations, being a paper presented at the conference on Fraud and the African Renaissance held in Uganda Martyrs University Uganda.

Robertson J. C. (1976) Fraud Awareness Auditing, Richard D. Irwin Chicago

Radizinowicz S. \& Wolfgang C. (1997): Crime and justice the Criminal Society of Nigeria Basic Books Inc. New York.

Stanley B. (1994) International Fraud McGraw - Hill, New York.

Smith R. G. (2002) "The Nature of Fraud in Victoria, Australia:

Smith, R. G. \& Grabosky P.N. (1998) "Taking fraud seriously: Issues and Strategies for reform", Institute of chattered accountants of Australia, Fraud advising council Sydney:

Sydney, I. F. (1986): Management Control System and the Prevention and Detection of Frauds in Banks. Lagos: CIBN \& Landmark Publications Ltd.

Dr. D. I. Hamilton is an Associate Professor in the department of Management, Faculty of Management Sciences, Rivers State University of Science and Technology, Port Harcourt, Nigeria.

Justin M. Odinioha Gabriel is a Lecturer and currently a PhD student in the department of Management, Faculty of Management Sciences, Rivers State University of Science and Technology, Port Harcourt, Nigeria. 